HIKMAH: Jurnal Pendidikan Islam Vol. 6, No. I Januari - Juni 2017

\title{
PEMIKIRAN PENDIDIKAN SYEKH NAWAWI AL-BANTANI
}

\author{
Bashori \\ Sekolah Tinggi Agama Isam (STAI) Tuanku Tambusai Pasir Pengaraian \\ Email: bashoribashori@gmail.com
}

\begin{abstract}
Abstrak
Sejarah ketokohan Ulama' di Indonesia berpengaruh dalam dimensi-dimensi sosial. Termasuk di dalamnya pengaruh terhadap dunia pendidikan Islam. Diantara para ulama yang terkenal di Indonesia adalah Syekh Imam Nawawi AlBantani, beliau adalah ulama' yang sangat terkenal, tidak hanya di Indonesia tapi juga dalam ranah Internasional di makkah. Beliau adalah ulama' yang ahli di bidang tafsir, tauhid, fiqh, tasawuf, sejarah nabi, bahasa dan retorika, karya-karya beliau memberikan sumbangan yang sangat besar dalam kemajuan islam di Indonesia, banyak sekali ulama' dan pejuang-pejuang islam yang berguru pada beliau, karena itulah jasa beliau sangat besar dalam mengislamkan Indonesia. Ketokohan Syekh Imam Nawawi Al-Bantani diakui secara luas, dia berkaliber regional, nasional dan bahkan berkaliber internasional, ia berhasil di Tiga posisi utama yang menjadikan nama Syekh Nawawi diperhitungkan banyak kalangan yaitu: a) Sebagai ulama yang sangat produktif dalam menulis dan mempunyai banyak karya; b) Syekh Nawawi merupakan salah satu pusat jaringan ulama dan pesantren; dan c) Syekh Nawawi adalah ulama jawi yang bermukim di Mekah dan mendapatkan banyak ilmu serta pengakuan dari dunia internasional. Sebagai posisinya sebagai ulama' besar, beliau juga memiliki konsep-konsep dalam makna pendidikan yang sebenarnya. Hal itu tampak dalam pandangan beliau dalam memaknai konsep kata pendidikan, Syekh Nawawi lebih condong kepada makna Ta'lim daripada Tarbiyah dan Ta'dib, dengan asumsi bahwa ta'lim tidak sekedar transfer ilmu, akan tetapi transformasi nilai dan metode. Dari asumsi tersebut, maka menarik untuk dikaji secara dalam pola pemikiran Syekh Nawawi alBantani dalam relevansinya dengan dunia pendidikan saat ini.
\end{abstract}

Kata Kunci: Pemikiran, Pendidikan, Syekh Nawawi al-Bantani

\section{PENDAHULUAN}

Sejarah telah mencatat bahwa Islam sudah masuk Indonesia sejak abad ke-7 M, yaitu melalui para saudagar Arab yang singgah di pesisir Sumatera Utara, yang mana menjadi tempat persinggahan pelayaran antara Arab dan Asia Timur. Dalam persinggahan itulah akhirnya terciptalah masyarakat muslim di Sumatera. Itu semua dimulai dari hubungan perkawinan antara pedagang Arab dan masyarakat 
pribumi, dan hal itulah yang menjadi faktor utama berkembangnya agama Islam di Indonesia. ${ }^{1}$

Dilihat dari sejarah berkembangnya agama Islam khususnya di Indonesia, tidak terlepas daripada peran para ulama-ulama, yang mana mereka selalu eksis dalam menyebarkan serta mengembangkan agama Islam. Ulama-ulama yang tersebar di pulau-pulau yang ada di Indonesia berperan aktif dalam penyebaran agama Islam, dari sinilah agama Islam mulai tersebar luas baik di pulau Sumatera sampai pulau Jawa atau di pulau-pulau lainnya.

Di antara para ulama yang terkenal di Indonesia adalah Syekh Imam Nawawi Al-Bantani, beliau adalah ulama' yang sangat terkenal, tidak hanya di Indonesia tapi juga di makkah, beliau adalah ulama' yang ahli di bidang tafsir, tauhid, fiqh, tasawuf, sejarah nabi, bahasa dan retorika, karya-karya beliau memberikan sumbangan yang sangat besar dalam kemajuan islam di Indonesia, banyak sekali ulama' dan pejuang-pejuang islam yang berguru pada beliau, karena itulah jasa beliau sangat besar dalam mengislamkan Indonesia.

Ketokohan Syekh Imam Nawawi Al-Bantani diakui secara luas, dia berkaliber regional, nasional dan bahkan berkaliber internasional, ia berhasil di bidang ilmu-ilmu keagamaan dan juga menjadi maha guru dari ulama ternama di Indonesia, akan tetapi pemikiran pendidikannya masih bertebaran, maka perlu dikonstruksi menjadi pemikiran pendidikan Islam yang utuh dan sistematis. ${ }^{2}$

Dalam tulisan ini, penulis tertarik mengkaji pemikiran Syekh Nawawi AlBantani, khususnya pemikirannya dalam pendidikan Islam dan relevansinya terhadap dunia modern. Dalam kajian ini diawali dengan menelaah biografi Syekh Nawawi al-Bantani, selanjutnya dilanjutkan menelaah bagaimana relevansi pemikiran Syekh Nawawi tentang pendidikan di dunia modern.

\footnotetext{
${ }^{1}$ Harun Asrohah, Sejarah Pendidikan Islam (Jakarta: Logos, 1999), hlm. 140.

${ }^{2}$ Maragustam, Pemikiran Pendidikan Syekh Nawawi Al-Bantani (Yogyakarta: Datamedia, 2007), hlm. 1 .
} 


\section{KAJIAN TEORI}

\section{Biografi Syekh Nawawi Al-Bantani}

Nama lengkapnya adalah Abu Abdul Mu'ti Muhammad bin Umar bin Arbi bin Ali Al-Tantara Al-Jawi Al-Bantani. Ia lebih dikenal dengan sebutan Muhammad Nawawi Al-Jawi Al-Bantani. ${ }^{3}$ Dalam beberapa halaman judul kitab karangannya, tercantum nama-nama dan sebutan bermacam-macam, terkadang memperkenalkan tanah asalnya, atau kepakarannya atau namanya dan silsilahnya. Seperti, Syekh Muhammad Nawawi Al-Jawy, Syekh Muhammad Nawawi bin Umar Nawawi Al-Jawy, Muhammad bin Umar bin Arbi bin Ali, Syekh Muhammad bin Umar Nawawi Al-Jamy. Nama yang paling panjang terdapat dalam salah satu karyanya, Nihayah yaitu Abu 'Abdul Mu'thi Muhammad bin Umar bin Ali Nawawi al-Jawy al-Bantani al-Tanara. ${ }^{4}$ Dilahirkan di kampung Tanara, kecamatan Tirtayasa, kabupaten Serang, Banten pada tahun $1813 \mathrm{M}$ atau 1230 H. ${ }^{5}$ dan wafat di Ma'la Mekah Saudi Arabia pada tahun 1897 M bertepatan dengan tanggal 25 Syawwal $1314 \mathrm{H}$ dalam usia 84 tahun. ${ }^{6}$ Menurut pelacakan geneologi, Syekh Nawawi adalah keturunan yang ke 12 dari Maulana Syarif Hidayatullah (Sunan Gunung Jati Cirebon), yaitu keturunan dari putera Maulana Hasanuddin (Sultan Banten I) yang bernama Sunyararas (Tajul 'Arsy). ${ }^{7}$

Silsilah keturunan Syekh Nawawi dari ayahnya adalah Nawawi bin kiai Umar bin Kiai Arabi bin Kiai Ali bin Kiai Jamad bin Janta bin Kiai Masbugil bin Kiai Tajul 'Arsy Tanara bin Maulana Hasanuddin Banten bin Maulana Syarif Hidayatullah Cirebon bin Maulana Jamaluddin Akbar Husain bin Imam Sayyid Ahmad Syah Jalal bin Abdullah Adzmah Khan bin Amir Abdullah Malik bin Sayyid Ali Khali' Qasim bin Sayyid Alwi bin Imam Ubaidillah bin Imam Ahmad Muhajir Ilallahi bin Imam Isa an-Naqib bin Imam Muhammad Naqib bin Imam Ali Aridhi bin Imam Ja'far ash-Shadiq bin Imam Muhammad al-Baqir bin Imam

\footnotetext{
${ }^{3}$ Muhammad Ulul fahmi, Ulama Besar Indonesia Biografi dan karyanya (Kendal: Amanah Grafika, 2008), hlm. 4.

${ }^{4}$ Maragustam, Pemikiran Pendidikan..., hlm. 99.

${ }^{5}$ Muhammad Ulul fahmi, Ulama Besar Indonesia Biografi dan karyanya (Kendal: Amanah Grafika, 200), hlm. 4.

${ }^{6}$ Maragustam, Pemikiran Pendidikan..., hlm. 100.

${ }^{7}$ Ibid, hlm. 100.
} 
Ali Zainal Abidin bin Sayyidina Husain bin Sayyidatuna Fathimah Zahra binti Muhammad Rasulullah SAW. Adapun dari silsilah dari ibunya adalah bahwa Nawawi putera Nyai Zubaidah binti Muhammad Singaraja. ${ }^{8}$

\section{Perjalanan Intelektual Syekh Nawawi al-Bantani}

Awal perjalanan intelektual Syekh Nawawi dimulai saat dia berumur 5 tahun yang langsung belajar dibawah asuhan ayahandanya. Ketika berumur 8 tahun dimulailah pengembaraannya untuk mencari ilmu di Jawa Timur, ${ }^{9}$ setelah 3 tahun belajar di Jawa Timur dia melanjutkan ke salah satu pondok di daerah Cikampek (Jawa Barat) untuk mendalami Lughoh (bahasa). Tidak lama belajar disana dia dipercaya untuk mengasuh pondok yang telah dirintis oleh ayahnya, di usianya yang masih relatif muda.

Pada usia 15 tahun, ia mendapatkan kesempatan untuk pergi ke Mekkah untuk menunaikan ibadah haji. Disana dia memanfaatkan untuk mendalami beberapa cabang ilmu seperti: Ilmu Kalam, ilmu bahasa arab dan sastra, ilmu hadits tafsir dan fiqih. Setelah 3 tahun belajar di Makkah dia kembali ke daerahnya untuk membantu ayahnya mengajar para santri di pondok. Namun beberapa tahun kemudian dia memutuskan untuk kembali ke Makkah ${ }^{10}$ dengan tujuan mukim dan menetap disana. ${ }^{11}$

Dalam buku yang di tulis Sudirman Tebba disebutkan bahwa Syekh Nawawi Al-Bantani untuk pertama kalinya belajar di Masjidil Haram Mekkah. Disana dia belajar pada Sayyid Ahmad Nakhrawi, Syekh Sayyid Ahmad Dimyati dan Syekh Sayyid Ahmad Zaini Dahlan. ${ }^{12}$ Setelah itu di Madinah dia belajar dengan Syekh Muhammad Khatib al-Hambali. ${ }^{13}$ Pencariannya terhadap ilmu tidak

\footnotetext{
${ }^{8}$ Sudirman Tebba, Mengenalkan Wajah Islam Yang Ramah (Banten: Pustaka Irvan, 2007), hlm. 156

9 Sebelum keberangkatannya, Nawawi harus menyanggupi syarat yang diajukan oleh ibunya, “Kudo'akan dan kurestui kepergianmu mengaji dengan syarat jangan pulang sebelum kelapa yang sengaja kutanam ini berbuah."

${ }^{10}$ Di antara penyebabnya adalah karena ia tidak dapat mengembangkan ilmunya karena saat itu negara Indonesia memang sedang dijajah Belanda. Akhirnya, Nawawi kembali ke Mekkah dan tinggal di daerah Syi'ab 'Ali. (Biografi-Syekh-Nawawi-Al-Bantani-al.html)

${ }^{11}$ Muhammad Ulul fahmi, Ulama Besar Indonesia..., hlm. 6-7.

${ }^{12}$ Sudirman Tebba, Mengenalkan Wajah Islam..., hlm. 157.

${ }^{13}$ Muhammad Ulul fahmi, Ulama Besar Indonesia..., hlm. 7.
} 
berhenti sampai disitu, tetapi dia juga pergi ke negara-negara lain seperti Mesir, Suria, disana dia juga belajar dengan ulama-ulama besar. ${ }^{14}$

\section{Pengaruh Pemikiran Syekh Nawawi Al-Bantani}

Nama Syekh Nawawi Al-Bantani sudah tidak asing lagi di kalangan umat Islam Indonesia. Bahkan kebanyakan orang-orang menjulukinya sebagai Imam Nawawi kedua. Melalui karya-karyanya yang tersebar di pesantren-pesantren tradisional yang sampai sekarang masih banyak dikaji, nama kyai asal Banten ini seakan-akan masih hidup dan terus menyertai umat memberi wejangan ajaran Islam yang menyejukkan. Di setiap majlis ta'lim karyanya selalu dijadikan rujukan utama dalam berbagai ilmu, dari ilmu tauhid, fiqih, tasawuf sampai tafsir.

Dikalangan komunitas pesantren Syekh Nawawi tidak hanya dikenal sebagai penulis kitab, akan tetapi sebagai mahaguru sejati (The Great Scholar). Nawawi telah banyak berjasa meletakkan landasan theologis dan batasan-batasan etis tradisi keilmuan di lembaga pendidikan pesantren. Ia turut banyak membentuk keintelektualan tokoh-tokoh para pendiri pesantren. ${ }^{15}$

Diungkapkan oleh Azumardi Azra yang dikutip oleh Maragustam bahwa Syekh Nawawi sebagai ulama yang tidak saja mumpuni dalam bidangnya, tapi juga disegani baik dikalangan dunia intelektualisme Indonesia maupun di kalangan dunia Timur Tengah dan Internasional umumnya. Disebutkan dalam buku tersebut bahwa Syekh Nawawi mempunyai tiga posisi utama yang membuat namanya diperhitungkan banyak kalangan. Pertama, sebagai ulama yang sangat produktif dalam menulis dan mempunyai banyak karya, bahkan ada yang bilang sampai ratusan judulnya bukunya. Kedua, Syekh Nawawi merupakan salah satu pusat jaringan ulama dan pesantren. Ini dapat dilihat dari sejarahnya dia belajar di Mekkah kemudian tidak sedikit orang yang berguru kepadanya, termasuh K.H. Hasyim Asy'ari dan beberapa ulama ternama di Madura. ${ }^{16}$ Di sinilah dia menjadi

\footnotetext{
${ }^{14}$ Sudirman Tebba, Mengenalkan Wajah Islam..., hlm.156.

${ }^{15}$ Muhammad Ulul fahmi, Ulama Besar Indonesia..., hlm. 9-10.

16 Diantara murid-murid Syekh Nawawi yang menjadi ulama besar dan tokoh-tokoh nasional, mereka adalah: Syekh Kholil Bangkalan, Madura, KH. Hasyim Asy'ari dari tebu ireng Jombang (Pendiri Organisasi NU), KH. Asy'ari dari Bawean, KH. Tubagus Muhammad Asnawi dari Caringan Labuan, Pandeglang Banten, KH. Tubagus Bakri dari Sempur-Purwakarta, KH. Abdul Karim dari Banten: Muhammad Ulul Fahmi, Ulama Besar Indonesia..., 9.
} 
semacam puncak dari sumber tradisi pesantren. Dan ketiga, Syekh Nawawi adalah ulama jawi yang bermukim di Mekah dan mendapatkan banyak ilmu serta pengakuan dari dunia internasional. ${ }^{17}$

\section{PEMBAHASAN}

\section{Pemikiran Pendidikan Syekh Imam Nawawi Al-Bantani}

\section{Hakikat pendidikan dan pengajaran dalam Islam}

Pendidikan pada hakikatnya adalah kegiatan yang dilakukan oleh orang yang bertanggung jawab, baik secara formal, informal atau nonformal, dalam hal ini pendidikan Islam bertujuan agar siswa memiliki ilmu pengetahun dan ketrampilan dalam rangka berbuat baik sesama manusia, beribadah kepada Allah, dan semakin dekat dengan Allah, disamping itu siswa diharapkan tidak hanya belajar nilai-nilai moral saja, akan tetapi dapat memberikan makna nilai-nilai tersebut dalam kehidupan sehari-hari yang Islami. ${ }^{18}$

Dalam hal ini, Maragustam mengungkapkan dalam bukunya bahwa belum ada kesepakatan secara pasti dari para ahli tentang kata yang tepat untuk memberi gambaran tentang pendidikan, ada yang memaknai dengan kata ta'lim, tarbiyah dan juga ta'dib. Perbedaan tersebut pada prinsipnya karena perbedaan pendekatan yang mereka gunakan, ada yang mendekatinya dari segi bahasa, segi konteks kedudukan kata dalam rangkaian kalimat-kalimat Al-Qur'an dan Hadits, dan ada pula pemilihan ayat atau hadits yang sesuai dari kata ta' lim, tarbiyah dan ta' dib. ${ }^{19}$

Berkaitan dengan pemaknaan kata ta'lim, tarbiyah dan juga ta'dib, terdapat beberapa ayat-ayat yang bisa dijadikan referensi dalam menentukan hakikat pendidikan Islam, ${ }^{20}$ diantaranya:

\footnotetext{
${ }^{17}$ Maragustam, Pemikiran Pendidikan..., hlm. 7-8.

18 Imam Machali, Pendidikan Islam \& Tantangan Globalisasi (Yogyakarta: Ar-Ruzz Media, 2004), hlm. 26-27.

${ }^{19}$ Maragustam, Pemikiran Pendidikan..., hlm. 200.

20 Diambil dari kutipan Maragustam dan Imam Machali dalam memaknai hakikat pendidikan dalam Islam.
} 
HIKMAH: Jurnal Pendidikan Islam Vol. 6, No. I Januari - Juni 2017

\section{a) Ayat-ayat tentang Ta'lim}

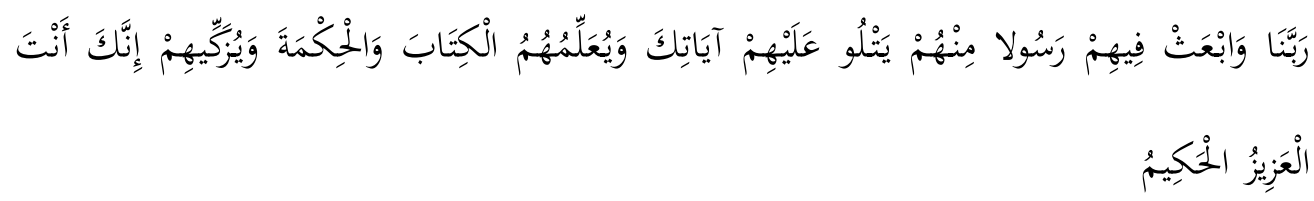

Artinya : Ya Tuhan Kami, utuslah untuk mereka sesorang Rasul dari kalangan mereka, yang akan membacakan kepada mereka ayat-ayat Engkau, dan mengajarkan kepada mereka Al kitab (Al Quran) dan Al-Hikmah (As-Sunnah) serta mensucikan mereka. Sesungguhnya Engkaulah yang Maha Kuasa lagi Maha Bijaksana (Al-Baqarah : 129)

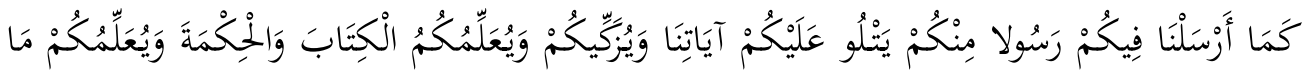

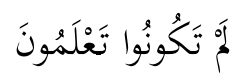

Artinya : Sebagaimana (kami telah menyempurnakan nikmat Kami kepadamu) Kami telah mengutus kepadamu Rasul diantara kamu yang membacakan ayatayat Kami kepada kamu dan mensucikan kamu dan mengajarkan kepadamu Al kitab dan Al-Hikmah, serta mengajarkan kepada kamu apa yang belum kamu ketahui (Al-Baqarah : 151)

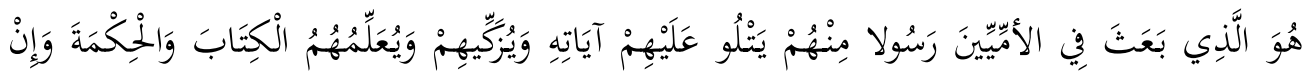

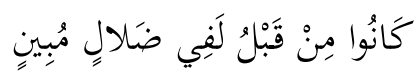

Artinya : Dia-lah yang mengutus kepada kaum yang buta huruf seorang Rasul di antara mereka, yang membacakan ayat-ayat-Nya kepada mereka, mensucikan mereka dan mengajarkan mereka kitab dan Hikmah (As Sunnah). dan Sesungguhnya mereka sebelumnya benar-benar dalam kesesatan yang nyata (AlJumu'ah : 2)

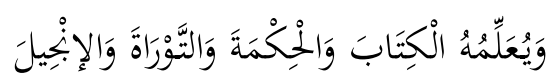

Artinya : Dan Allah akan mengajarkan kepadanya Al Kitab, hikmah, Taurat dan Injil (Ali Imran : 48) 
Dari empat ayat di atas, Syekh Nawawi menafsirkan bahwa membacakan dalam ayat ini bukan hanya sebatas membacakan saja, akan tetapi membacakan dengan mengarahkan manusia kepada iman, sedangkan makna mengajarkan (ta'lim)Al-kitab, Nawawi memberikan makna yang lebih luas, yaitu mengajarkan dan memahamkan nilai-nilai dari ajaran tersebut serta bagaimana mengimplementasikan ajaran tersebut dalam kehidupan sehari-hari. ${ }^{21}$

Maragustam menjelaskan lebih jelas, yang juga dikutip dari tafsir karangan Syekh Nawawi bahwa proses ta'lim dalam Islam mencakup transfer (pemindahan) ilmu, nilai dan metode dan trasformasi (hal-hal yang diterima peserta didik itu menjadi miliknya dan dapat merubah serta membentuk pribadinya). Karena dalam mengajarkan tilawah Al-qur'an dan sunnah tidak terbatas pada bahwa nabi Muhammad SAW menyuruh umatnya untuk sekedar membaca Al-qur'an, akan tetapi juga mengajari mereka kandungannya yakni perintah dan larangan, mengimani kebenarannya dan mengingatkannya dengan menunjukkan berbagai bukti-bukti kebesaran Allah. Cara membaca seperti ini tentu tidak sekedar dapat membaca Al-quran dengan tajwid, melainkan membaca dengan perenungan dan berisikan pemahaman, pengertian, tanggung jawab dan penanaman amanah. ${ }^{22}$

Jadi makna (Ta'lim) yang terkandung dalam ayat ini adalah suatu kegiatan pengajaran yang bersumberkan kepada ajaran agama yang berisi nilai-nilai keagamaan yang mana ajaran tersebut hendaklah di terapkan dalam kehidupan seseorang.

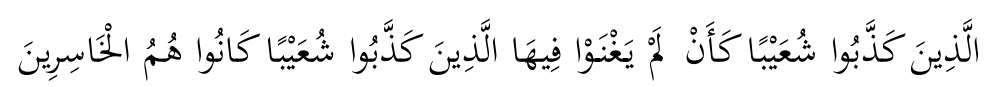

Artinya: Jikalau Sekiranya penduduk negeri-negeri beriman dan bertakwa, pastilah Kami akan melimpahkan kepada mereka berkah dari langit dan bumi, tetapi mereka mendustakan (ayat-ayat Kami) itu, Maka Kami siksa mereka disebabkan perbuatannya (Al-A'raf : 96)

Dalam ayat ini Syekh Nawawi menjelaskan bahwa berkah dari Allah akan diturunkan kepada hamba mereka yang beriman dan bertaqwa, dan Allah akan

\footnotetext{
${ }^{21}$ Syekh Muhammad Nawawi, Murah labayd (Mesir: Darul Ihya'Al-Kutb Al-'Arabiyah, Tanpa Tahun), hlm. 35 .

${ }^{22}$ Maragustam, Pemikiran Pendidikan..., hlm. 202.
} 
menggantikan nikmat mereka dengan siksaan manakala mereka mendustakan ayat-ayat Allah, dan itu semua adalah akibat daripada perbuatan yang mereka kerjakan. $^{23}$

Dari ayat ini dapat disimpulkan bahwa Pendidikan menurut Syekh Nawawi tidak cukup dengan pengajaran saja, akan tetapi bagaimana mengimplementasikan ajaran tersebut dalam kehidupan sehari-hari, yang mana itu semua berasaskan pada nilai keimanan dan ketaqwaan, sehingga pendidikan tersebut membawakan berkah yang melimpah.

\section{b) Ayat-ayat tentang Tarbiyah}

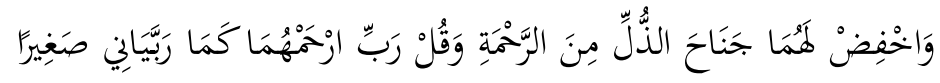

Artinya: Dan rendahkanlah dirimu terhadap mereka berdua dengan penuh kesayangan dan ucapkanlah: "Wahai Tuhanku, kasihilah mereka keduanya, sebagaimana mereka berdua telah mendidik aku waktu kecil". (Al-Isra' : 24)

$$
\text { قَالَ أَلَهْ نُرَبِّكَ فِينَا وَلِيدًا وَلَبْنْتَ فِينَا ِِنْ عُمُرِكَ سِنِينَ }
$$

Artinya: Fir'aun menjawab: "Bukankah Kami telah mengasuhmu di antara (keluarga) Kami, waktu kamu masih kanak-kanak dan kamu tinggal bersama Kami beberapa tahun dari umurmu (As-Syu'araa': 18)

Dalam ayat ini tarbiyah lebih ditekankan kepada pendidikan anak diwaktu kecil, Syekh Nawawi menafsirkan ayat pertama sebagai perintah bahwa kita wajib berbuat baik kepada kedua orang tua kita dan juga mendoakannya walaupun hanya lima kali dalam sehari, karena kedua orang tua kitalah yang telah mendidik kita dari kecil hingga dewasa. ${ }^{24}$ Di ayat kedua lebih ditekankan bahwa pendidikan anak mulai kanak-kanak, hal tersebut ditafsirkan oleh Nawawi bahwa Nabi Musa diasuh oleh Fir'aun dari kanak-kanak dirumah Fir'aun sampai umur 30 tahun, dan ada juga yang berkata 15 tahun diasuh dirumahnya Fir'aun. ${ }^{25}$

\footnotetext{
${ }^{23}$ Syekh Muhammad Nawawi, Murah labayd..., hlm. 291.

${ }^{24}$ Ibid., hlm. 376.

25 Syekh Muhammad Nawawi, Murah labayd Juz 2 (Mesir: Darul Ihya'Al-Kutb Al'Arabiyah, Tanpa Tahun), hlm. 105-106.
} 
c) Dalam ayat yang menerangkan tentang Ta'dib, Nawawi menafsirkan Ayat 6 dalam surat At-Tahriim yang berbunyi

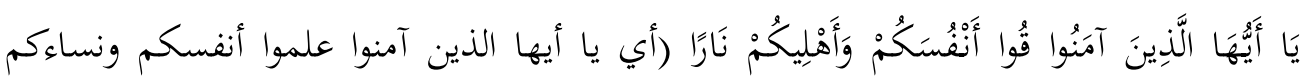

$$
\begin{aligned}
& \text { وأولادكم الخير وأدبوهم بأن تأمرهم بالخير وتنهون عن الشر تقوهم بذلك النار) }
\end{aligned}
$$

Artinya: Wahai orang-orang yang beriman, 'allimuи ajarilah dirimu dan istrimu serta anakmu untuk berbuat kebaikan, dan Addibuu (didiklah istrimu serta anakmu dan setiap orang yang masuk dalam tanggunganmu tentang kebagusan akhlaq), dengan cara menyuruh mereka untuk berbuat kebaikan dan melarang mereka untuk berbuat kejahatan, hal itulah yang menyelamatkan kamu dari api neraka.

Dikutip oleh Maragustam dari Syarh 'Uqud karangan Nawawi bahwa Nawawi mengartikan ta'dib disamakan dengan ta'lim, akan tetapi ta'dib lebih ditekankan kepada pembentukan Akhlaq. Dengan demikian, Nawawi tidak terlalu membedakan antara makna ta'lim dan ta'dib, karena semuanya mengacu kepada trasformasi dalam pendidikan. ${ }^{27}$

\section{Sumber pemikiran pendidikan Islam}

Berbicara tentang pendidikan Islam, kita tidak akan terlepas dari tujuan utama diciptakannya manusia di bumi ini, yaitu untuk menjadi khalifah yang tugasnya adalah beribadah kepada Allah. Untuk mengaplikasikan tujuan tersebut dibutuhkannya sebuah pengamalan, pengembangan serta pembinaan yang mana itu semua terealisasikan dalam wadah pendidikan Islam. ${ }^{28}$

Terkait dengan pendidikan Islam, sudah seharusnya sumber-sumber yang dipakai dalam pendidikan tersebut adalah berasal dari agama Islam, dalam hal ini Nahlawi menyampaikan bahwa sumber pendidikan Islam adalah Al-Qur'an dan Sunnah An-Nabawiyyah. Dan Al-qur'an sebagai sumber utama sudah tidak diragukan lagi, karena keberadaan Al-qur'an telah mempengaruhi sistem pendidikan Rasulullah SAW dan para sahabat. Terlebih ketika Aisyah istri

\footnotetext{
${ }^{26}$ Syekh Muhammad Nawawi, Murah labayd Juz 2..., hlm. 276.

${ }^{27}$ Maragustam, Pemikiran Pendidikan..., hlm. 206-207.

28 Abdurrahman An-Nahlawi, Pendidikan Islam di Rumah, Sekolah dan Masayarakat (Jakarta: Gema Insani, 2004), hlm.25.
} 
Rasulullah menyampaikan bahwa akhlaq Rasulullah adalah Al-qur'an. Ditegaskan lagi dalam firman Allah:

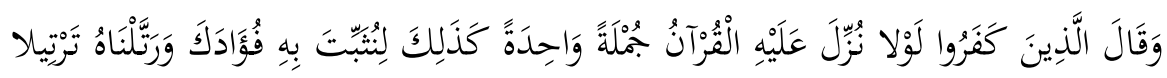

Artinya: berkatalah orang-orang yang kafir: "Mengapa Al Quran itu tidak diturunkan kepadanya sekali turun saja?"; demikianlah, supaya Kami perkuat hatimu dengannya dan Kami membacanya secara tartil (teratur dan benar). (AlFurqan : 32)

Sumber yang kedua setelah Al-qur'an adalah As-Sunnah. Nahlawi berpendapat bahwa keberadaan As-Sunnah pada hakikatnya ditujukan untuk mewujudkan dua sasaran yaitu: pertama, menjelaskan apa yang terdapat dalam Al-Qur'an yang berupa konsep-konsep dan kesempurnaan pendidikan Islam. Kedua, menjelaskan syari'at dan pola perilaku yang dilakukan oleh Rasulullah SAW. $^{29}$

Pendapat di atas sedikit berbeda dengan pendapat Syekh Nawawi, menurutnya sumber pemikiran pendidikan Islam tidak hanya dengan Al-qur'an dan As-Sunnah, beliau menambahkan Ijama', Qias, Ijtihad serta pendapat para ahli salaf as-shalih sebagai sumber pendidikan dalam Islam. Dalam melakukan ijtihad, Syekh Nawawi menggunakan metode qias, serta menafsirkan kembali ayat-ayat Al-qur'an dan Sunnah serta mendialogkan pemikirannya dengan pendapat para ahli salaf as-shaleh. ${ }^{30}$

\section{Tujuan pendidikan Islam}

Pada hakikatnya tujuan pendidikan Islam adalah idelaitas (cita-cita), yaitu idealitas yang mengandung nilai-nilai Islami yang mana itu semua dicapai dalam proses kependidikan yang berdasarkan ajaran Islam secara bertahap. Dalam hal ini Arifin menyampaikan, bahwa pendidikan Islam merupakan penggambaran nilainilai islami yang berhak diwujudkan dalam pribadi manusia didik pada akhir dari proses sebuah pendidikan. ${ }^{31}$

\footnotetext{
${ }^{29}$ Ibid, hlm. 31-32.

${ }^{30}$ Maragustam, Pemikiran Pendidikan Syekh Nawawi Al-Bantani..., hlm. 208.

31 M. Arifin, Ilmu Pendidikan Islam, Tinjauan Teoritis dan Praktis Berdasarkan Pendekatan Interdisipliner (Jakarta:Bumi Aksara, 2003), hlm. 54.
} 
Sedangkan Muhammad 'Athiyyah menyimpulkan bahwa tujuan pendidikan dan pengajaran bukanlah sebatas memenuhi otak anak didik dengan segala macam ilmu yang belum mereka ketahui, melainkan: a) Mendidik akhlaq dan jiwa anak; b) Menanamkan rasa keutamaan; c) Membiasakan mereka dengan kesopanan yang tinggi; dan d) Mempersiapkan mereka untuk suatu kehidupan dengan penuh keihklasan dan kejujuran. ${ }^{32}$

Sedangkan Syekh Nawawi dalam menentukan tujuan pendidikan mengambil dari penjelasannya tentang tujuan peserta didik menuntut ilmu dan juga fungsi manusia di bumi sebagai khalifah yang tugasnya beribadah kepada Allah yang mana itu semuanya tertulis dalam firman Allah:

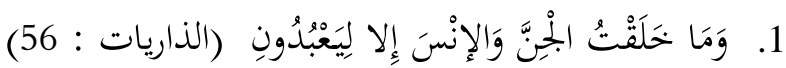

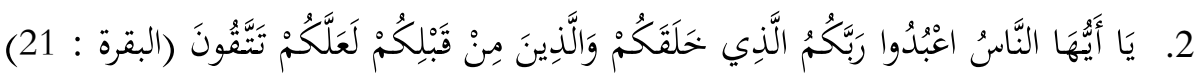

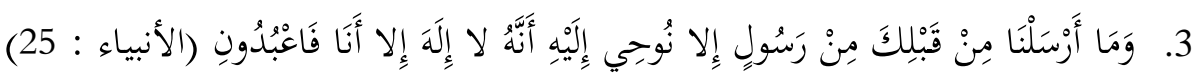

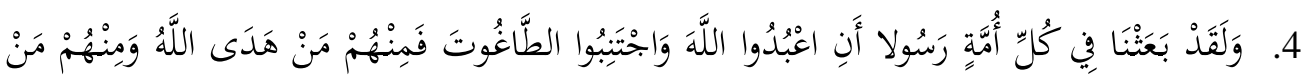

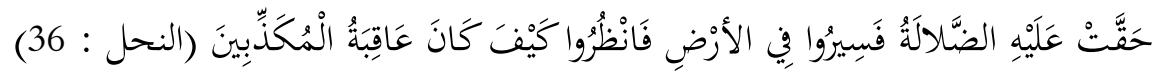

Dari ayat-ayat di atas Syekh Nawawi berpendapat bahwa tujuan pendidikan dalam Islam merupakan sebuah refleksi dari fungsi manusia untuk beribadah kepada Allah dan menjadi khalifah di muka bumi, dan Nawawi mengklasifikasikannya sebagai berikut: 1) Pendidikan Islam agar memperoleh ridho dari Allah dan memperoleh kehidupan di akhirat; 2) Pendidikan Islam berguna untuk menyingkirkan kebodohan dari dalam diri manusia, dan mengajarkan apa yang sudah dia pelajari kepada orang lain agar kebodohan itu lenyap; 3) Pendidikan Islam untuk menghidupkan agama dan mengabadikan Islam dengan sinaran ilmu; dan 4) Pendidikan Islam untuk mensyukuri nikmat Allah berupa akal dan badan yang sehat. ${ }^{33}$

\footnotetext{
${ }^{32}$ Muhammad 'Atthiyyah AL-Abrasyi, Prinsip-prinsip dasar Pendidikan Islam (Bandung: Pustaka Setia, 2003), hlm.13.

${ }^{33}$ Maragustam, Pemikiran Pendidikan..., hlm. 210-211.
} 
Dari pendapat Syekh Nawawi diatas dapat diambil kesimpulan bahwa pendapat syekh Nawawi senada dengan pendapat Arifin, yang mana tujuan daripada pendidikan adalah idealitas, idealis dalam presprektif Nawawi adalah pendidikan karena mengharapkan ridho Allah dan kebahagiaan kelak di akhirat. Akan tetapi Nawawi menambahkan tujuan realistis dalam pendidikan Islam, yaitu menghilangkan kebodohan yang ada pada manusia serta mengabaikan Islam dengan sinaran ilmu-ilmu agama.

\section{Prinsip-prinsip metode pendidikan Islam}

Pada prinsipnya, metode pendidikan Islam sangat efektif dalam membina kepribadian anak didik dan memotivasi mereka sehingga nilai keislaman dapat teraplikasikan dalam dunia pendidikan secara meluas. Dalam hal ini Nahlawi menklasifikasikan beberapa metode yang relevan dalam perkembangan pendidikan Islam yaitu: a) Metode dialog Qur'ani dan Nabawi; b) Mendidik melalu kisah-kisah Qur'ani dan Nabawi; c) Mendidik melalui perumpamaan Qur'ani dan Nabawi; d) Mendidik melalui keteladanan; e) Mendidik melalui aplikasi dan pengalaman; f) Mendidik melalui ibrah dan nasehat; g) Mendidik melalui targhib $^{34}$ dan tarhib. ${ }^{35}$

Lain lagi dengan Muhammad 'Athiyyah yang mengutip pendapat Imam Ghozali dan Ibnu Kholdun, menurut Imam Ghozali metode pengajaran yang dipergunakan dalam mengajar anak-anak harus berbeda dengan metode yang digunakan untuk mengajar orang-orang besar. Imam Ghozali berkata:

"Kewajiban utama dari seorang pendidik ialah mengajarkan kepada anakanak setiap masalah yang mudah dan dapat difahaminya. Karena masalahmasalah yang pelik justru akan mengakibatkan kerancuan pikiran dan menyebabkan ia melarikan diri dari ilmu"

Senada dengan Ibnu Kholdun yang berkata:

${ }^{34}$ Kata Targhib diambil dari kata kerja raghaba yang berarti menyenangi, menyukai dan mencintai. Kemudian diubah menjadi kata benda targhib yang mengandung makna suatu harapan untuk memperoleh kesenangan, kecintaan, kebahagiaan. Sedangkan kata Tarhib berasal dari kata rahhaba yang berarti menakut-nakuti atau mengancam, lalu dirubah menjadi kata benda yaitu tarhib yang berarti ancaman atau hukuman.

${ }^{35}$ Abdurrahman An-Nahlawi, Pendidikan Islam di Rumah..., hlm. 204. 
"Banyak kita lihat dewasa ini ini para pengajar yang tidak mengerti cara mengajar dan memanfaatkan pelajaran, pada permulaan saja, mereka telah memberikan masalah-masalah yang sulit kepada para murid dan memintanya untuk memecahkan masalah tersebut, dan mereka anggap cara itulah yang sebaik-baiknya untuk melatih anak-anak dan cara itulah yang benar. Padahal sesungguhnya kemauan dan kesediaan adalah sesuatu yang datang secara berangsur." 36

Dalam masalah ini Syekh Nawawi mempunyai pendapat tidak jauh berbeda dari pendapat Imam Ghozali dan juga Ibnu Ibnu Kholdun, akan tetapi pemikiran Syekh Nawawi lebih mendalam, berikut adalah pemikiran Syekh Nawawi tentang prinsip dan metode pendidikan Islam: 1) Dalam menyajikan mata pelajaran dimulai dari yang paling mudah, yang konkrit, yang dapat ditangkap oleh akal pikiran peserta didik, baru kemudian bertahap dibawa kepada yang lebih sulit, abstrak dan komplek. Mendekatkan materi pengetahuan yang diajarkan dengan pemahaman peserta didik seiring dengan perkembangan usianya, tingkat kematangan bahasa dan inteleknya; 2) Prinsip mengetahui keadaan peserta didik, seperti kematangan dan perbedaan individual dan lain sebagainya; 3) Prinsip menggunakan metode mengajar yang berbeda sesuai dengan tingkat kemampuan watak peserta didik; 4) Prinsip pengajaran sebagai pengalaman yang menggembirakan; 5) Prinsip pengajaran sebagai pengalaman yang memberi kebebasan berfikir sehingga pendidik tidak perlu mendominasi percakapan; 6) Prinsip partisipasi aktif atau pengalaman langsung tentang materi yang disampaikan. Dengan kata lain pendidik adalah barisan terdepan dalam pengamalan apa yang akan diajarkannya; 7) Prinsip memberikan penjelasan mata pelajaran dengan penjelasan yang mudah dimengerti; dan 8) Prinsip pengulangan terkait pelajaran yang sudah pelajari. ${ }^{37}$

Dari pendapat di atas dapat diambil kesimpulan bahwa pendapat Syekh Nawawi tidak begitu berbeda dengan pendapat dari ulama lain terkait prinsipprinsip metode pendidikan Islam, bahkan pendapat yang dikemukan oleh Nawawi

\footnotetext{
${ }^{36}$ Muhammad 'Atthiyyah AL-Abrasyi, Prinsip-prinsip dasar Pendidikan Islam..., hlm. 25.

${ }^{37}$ Maragustam, Pemikiran Pendidikan Syekh Nawawi Al-Bantani, hlm. 222-223.
} 
jauh lebih luas penjelasannya. Sehingga secara umum pendapat yang diungkapkan oleh Syekh Nawawi dapat kita aplikasikan dalam pendidikan Islam, terutama di sekolah yang berbasis tradisional (agama).

\section{Pendidik dan peserta didik}

Pada hakekatnya pendidik merupakan pribadi-pribadi yang mendapatkan kehormatan dan kedudukan yang tinggi, kehormatan dan kedudukan tersebut akan didapatkan bila ilmu yang dipelajari bisa dikembangkan dan diamalkan secara terus menerus. ${ }^{38}$

Dalam hal ini syekh Nawawi berpendapat bahwa kedudukan pendidik sangatlah penting dalam perkembangan proses belajar mengajar, bahkan seorang peserta peserta didik yang tidak mempunyai pendidik maka pendidiknya adalah syaitan, hal itu sebagaimana pernyataan ulama yang mengatakan bahwa pohon yang tumbuh dengan sendirinya tidak akan berbuah, walaupun berbuah maka buahnya tidak lezat. Artinya seorang peserta didik dalam proses belajarnya harus dengan bimbingan pendidik. ${ }^{39}$

Berhubungan dengan pentingnya pendidik dalam perkembangan peserta didik, maka syekh Nawawi memberikan etika ketat bagi para pendidik yaitu: 1) Tabah dan sabar menerima segala persoalan yang dihadapkan peserta didik; 2) Senantiasa bermurah hati dalam berbagai hal; 3) Duduk berwibawa dengan cara terhormat sambil menundukkan kepala dan melonggarkan pandangan; 4) Tidak sombong kepada sesama manusia, kecuali kepada orang yang terang-terangan dzalim sebagai peringatan larangan atas kedzalimannya. Berbuat sombong kepada orang yang sombong itu adalah sedekah sebagaimana tawadhu kepada orang yang tawadhu; 5) Bersikap tawadhu dalam pertemuan-pertemuan dalam majelis; 6) Menghindari bercanda dan senda gurau; 7) Bersikap lemah lembut dan ramah tamah kepada peserta didik ketika mengajar dan sabar dalam menghadapi orang yang pandai mengungkapkan pertanyaan; 8) Mendidik anak yang tidak cerdas (idiot) dengan pengajaran yang baik; 9) Tidak marah-marah (membentak-bentak) dan tidak pula menyindir peserta didik yang bodoh dalam proses pengajarannya,

\footnotetext{
${ }^{38}$ Ibid., hlm. 224.

${ }^{39}$ Ibid., hlm. 227.
} 
tetapi dengan pengajaran yang baik; 10) Tidak merasa segan dan malu untuk berkata "saya tidah tahu" atau "Allah yang maha tau" jika suatau masalah belum dikuasainya atau belum belum diketahuinya; 11) Menyimak orang yang bertanya dan memahami pertanyaannya supaya dijawab dengan baik; 12) Dapat menerima argumen atau dalil dari orang lain dan menyimaknya walaupun argumentasi itu berasal dari yang bukan sefaham dengannya. Karena mengikuti kebenaran itu wajib; 13) Tunduk kepada kebenaran, dan kembali kepada kebenaran ketika melakukan kesalahan dalam berbicara atau memegang keyakinan, walaupun yang benar itu berasal dari orang yang lebih rendah derajatnya daripada pendidik sendiri; 14) Mencegah peserta didik dari setiap ilmu yang membahayaknnya dalam hal agama seperti ilmu sihir, ilmu nujum (perbintangan) dan astrologi; 15) Mencegah peserta didik belajar dan menggunakan ilmu yang bermanfaat demi selain mencari ridho Allah dan negeri akherat; 16) Mencegah peserta didik dari kesibukan kewajiban komunal sebelum mnyelesaikan kewajiban personal yaitu memperbaiki lahir dan batinnya dengan takwa yakni melaksanakan ibadah lahir dan batin serta menjauhi maksiat lahir batin; 17) Menginstrospeksi diri sendiri terlebih dahulu, sebelum memerintahkan orang lain mengerjakan kebaikan, dan sebelum melarang orang lain berbuat kejahatan dengan menjunjung tinggi perintah agama dan menjauhi larangannya, agar peserta didik dapat mengambil teladan dari perbuatan-perbuatannya dan mengambil manfaat dari ucapanucapannya. Karena petunjuk tingkah lebih kuat dan lebih berbobot dari petunjuk ucapan. $^{40}$

Dari etika pendidik menurut syekh Nawawi diatas, penulis dapat menyimpulkan bahwa hakikat daripada pendidik tidak cukup sebagai sarana untuk mentransfer ilmu dari otak pendidik ke otak peserta didik, akan tetapi lebih mengedepankan kepada pembentukan akhlaq mulia serta suri tauladan yang baik dari pendidik. Hal itu yang dapat mensukseskan pendidik dalam mendidik peserta didik.

Terlepas dari pendidik, hal yang lebih penting dari suksesnya sebuah proses belajar mengajar yaitu adanya peserta didik yang siap untuk menerima

\footnotetext{
${ }^{40}$ Ibid, hlm. 228-229.
} 
pengetahuan dari pendidik. Dalam hal ini Ahmad Syar'I menyampaikan bahwa peserta yaitu bukan hanya anak-anak kecil, akan tetapi mencakup seluruh manusia baik itu besar maupun kecil, tua maupun muda, kaya maupun miskin yang masih memerlukan pengetahuan dan ketrampilan tertentu dalam rangka memenuhi kebutuhan kehidupannya. ${ }^{41}$

Berkaitan dengan peserta didik, syekh Nawawi memberikan beberapa etika yang harus dikerjakan oleh para peserta didik dalam menghadapi pendidik dalam proses belajar mengajar yaitu: a) Lebih dulu memulai penghormatan, salam dan meminta ijin ketika memasuki majelis taklim; b) Mempersedikit bicara dan mempersedikit sesuatu yang diperbolehkan ketika berada dihadapan gurunya; c) Tidak mengatakan/berbicara hal yang tidak ditanyakan; d) Tidak bertanya tentang sesutu sebelum meminta ijin terlebih dahulu atau tidak bertanya sebelum ada persoalan; e) Tidak mengkontradiksikan pendapat gurunya dengan pendapat orang seperti misalanya "si fulan berbeda dengan pendapat anda atau yang semacamnya"; f) Tidak menunjukkan pendapat yang berbeda dengan pendapat gurunya, karena anggapan peserta didik bahwa dirinya lebih mengetahui kebenaran dalam masalah itu. Sikap demikian akan mengurangi sopan santun dan mengurangi berkah ilmunya; g) Jangan bertanya ke teman gurumu di tempat gurumu, dan tidak tersenyum ketika terjadi pembicaraan; h) Tidak menoleh ke kiri dan ke kanan ketika berada di depan gurunya, tapi duduk dengan menundukkan mata, diam, sopan, dan tidak menggerakkan badan, seolah-olah kamu sedang sholat; i) Tidak bertanya ketika pendidik tampak bosan dan bingung; j) Berdiri ketika pendidik berdiri untuk menghormatinya; k) Tidak menguntit pendidik ketika keluar majelis untuk mengajak bicara dan bertanya; 1) Tidak bertanya kepada pendidik di jalan, tapi harus menunggu pendidik sampai di rumahnya atau sampai tempat peristirahatannya; dan $\mathrm{m}$ ) Tidak berburuk sangka terhadap perbuatan pendidik yang secara lahiriah, menurut pandanganmu tidak diridhoi oleh Allah, karena pendidik itu lebih mengetahui rahasia-rahasia perbuatannya sendiri. $^{42}$

\footnotetext{
${ }^{41}$ Ahmad Syar'i, Filsafat Pendidikan Islam (Jakarta: Pustaka Firdaus, 2005), hlm. 44.

${ }^{42}$ Ibid, hlm. 229-230.
} 
Dari etika-etika di atas, penulis dapat menyimpulkan bahwa menghormati guru merupakan faktor terbesar dalam mendapatkan ilmu dari guru, jadi dalam hal ini Syekh Nawawi lebih menekankan penggunaan etika dalam proses menuntut ilmu sebagai syarat mendapatkan il mu dari guru.

\section{Relevansi Pemikiran Pendidikan Syekh Imam Nawawi Al-Bantani dengan Dunia Modern}

Sebagaimana yang telah tercantum dalam UU Republik Indonesia Nomor 14 tahun 2005 bab IV pasal 8 tentang guru, bahwa setiap guru dalam menjalankan tugasnya wajib memiliki kualifikasi akademik, kompetensi, sertifikat pendidik, sehat jasmani dan rohani, serta memiliki kemampuan untuk mewujudkan tujuan pendidikan. Yang mana hal-hal tersebut bertujuan untuk menciptakan peserta didik yang berkualitas baik dalam segi akademis maupun non akademis.

Berkaitan dengan kompetensi guru, maka dalam hal ini seorang guru harus menguasai 4 kompetensi yang mana kompetensi-kompetensi tersebut harus dikuasai guru untuk meningkatkan kualitas dalam dirinya dan kualitas peserta didik, karena pada hakekatnya peran aktif guru sangat besar dalam kemajuan peserta didik dalam proses belajar mengajarnya. Dan adapun kompetensikompetensi tersebut adalah: kompetensi pedagogik, kompetensi profesional, kompetensi sosial, dan kompetensi kepribadian. ${ }^{43}$

Ditinjau dari tiap kompetensi, kompetensi pedagogik lebih ditekankan bagaimana seorang guru dapat menguasai disiplin ilmu pendidikan dan juga ilmu lain yang berkaitan dengan tugasnya sebagai guru, ${ }^{44}$ kompetensi tersebut mencakup penguasaan guru terkait hal-hal yang menyangkut pribadi peserta didik, penguasaan guru terkait kemampuan pribadi pendidik dan juga pemanfaatan semua aspek yang mendukung perkembangan peserta didik.

Adapun implementasi daripada kompetensi profesional dapat dilihat dari bagaimana seorang menguasai ketrampilan dan keahlian dalam hal teoritik dan praktik dalam proses pembelajaran, baik dari segi metode mengajar ataupun dari ketrampilannya dalam memanfaatkan hal-hal yang mendukung dalam proses

\footnotetext{
${ }^{43}$ Janawi, Kompetensi Guru: Citra Guru Profesional (Bandung: Alfabeta, 2011), hlm. 4546.

${ }^{44}$ Ibid., hlm. 47.
} 
pembelajaran peserta didik. ${ }^{45}$ Dalam hal ini, penulis dapat menggaris bawahi bahwa seorang guru hendaklah bersikap aktif dalam perkembangan dirinya sendiri untuk menciptakan sebuah metode yang efektif dan efisien dalam peningkatan proses belajar mengajar.

Sedangkan kompetensi kepribadian lebih ditekankan kepada kemampuan personal guru sendiri, dalam hal ini kepribadian seorang pendidik harus dapat dijadikan panutan bagi para peserta didik, dengan kata lain seorang pendidik harus bisa menjadi suri tauladan dan menjadi sumber dasar bagi perkembangan peserta didik. $^{46}$ Dan dalam kompetensi ini penulis dapat menyimpulkan bahwa akhlaq mulia adalah hal terbesar yang harus dimiliki oleh seorang guru yang aktif dalam pengembangan para peserta didik, sehingga guru yang dalam proses belajar mengajarnya tidak menunjukkan etika baik, maka dia tidak berhak untuk menjadi seorang pendidik.

Dan kompetensi yang terakhir adalah kompetensi sosial, disini seorang guru diharapkan mampu berinteraksi dengan peserta didik dan dengan orang yang ada disekitar dirinya, dengan kata lain seorang guru hendaknya mempunyai strategi dan pendekatan dalam melakukan komunikasi terhadap peserta didik, sehingga pengetahuan yang ada pada guru dapat diterima oleh peserta didik dengan senang hati, tanpa ada unsur paksaan atau penekanan. ${ }^{47}$

Sejajar dengan kompetensi-kompetensi di atas, Syekh Nawawi sudah lebih dulu menyumbangkan pemikirannya terkait kompetensi tersebut, walaupun istilah pada zaman sekarang bisa dianggap lebih sistematis, akan tetapi banyak kesamaan antara pemikiran pendidikan modern dengan pemikian syekh Nawawi, selain itu dalam pandangan Nawawi beliau lebih mengedepankan kompetensi kepribadian dari kompetensi- kompetensi yang lain, karena ruh yang baik daripada pendidik akan memberikan konstribusi besar dalam perkembangan peserta didik.

Lebih mendalam lagi Syekh Nawawi dan juga para ahli pendidik muslim mengemukakan lebih ketat terkait persyaratan-persyaratan pendidik dan peserta didik, hal tersebut dikarenakan, (1). Seorang guru pengaruhnya sangat besar

\footnotetext{
${ }^{45}$ Ibid, hlm. 48.

${ }^{46}$ Ibid, hlm. 50.

${ }^{47}$ Ibid, hlm. 50 .
} 
dalam pembentukan kepribadian peserta didik. (2). Pendidikan berhubungan dengan tanggung jawab kemanusiaan dan keagamaan, karena akan dipertanggung jawabkan di dunia dan akhirat. (3). Guru merupakan cerminan kepribadian Nabi yang patut diteladani.

Dilihat dari penjelasan di atas, maka penulis dapat menyimpulkan bahwa pemikiran pendidikan menurut Syekh Nawawi sangat relevan apabila digunakan dalam dunia modern sekarang, hal tersebut dapat dilihat dari unsur-unsur daripada kompetensi guru yang mana di dalamnya terdapat kesamaan dengan pemikiran pendidikan Syekh Nawawi. Walaupun menurut pemikiran Nawawi lebih menitik beratkan kepada kompetensi kepribadian guru daripada kompetensi-kompetensi lain, hal tersebut karena kepribadian guru sangat berpengaruh besar terhadap perkembangan peserta didik semasa menjalani proses belajar mengajar, dan masa depan anak dapat dilihat dari bagaimana seorang guru memberikan pendidikan kepada anak, khususnya pendidikan ketika kecil.

\section{KESIMPULAN}

Dari beberapa pembahasan yang telah penulis paparkan di atas, maka penulis simpulkan beberapa hal sebagaimana berikut ini:

1. Tiga posisi utama yang menjadikan nama Syekh Nawawi diperhitungkan banyak kalangan: a) Sebagai ulama yang sangat produktif dalam menulis dan mempunyai banyak karya, bahkan ada yang bilang sampai ratusan judulnya bukunya; b) Syekh Nawawi merupakan salah satu pusat jaringan ulama dan pesantren. Ini dapat dilihat dari sejarahnya dia belajar di Mekkah kemudian tidak sedikit orang yang berguru kepadanya; dan c) Syekh Nawawi adalah ulama jawi yang bermukim di Mekah dan mendapatkan banyak ilmu serta pengakuan dari dunia internasional.

2. Dalam mengartikan kata pendidikan, Nawawi lebih condong kepada makna Ta'lim daripada Tarbiyah dan Ta'dib, dengan asumsi bahwa ta'lim tidak sekedar transfer ilmu, akan tetapi transformasi nilai dan metode. 
3. Sumber pemikiran pendidikan Islam tidak hanya dengan Al-qur'an dan AsSunnah, Nawawi menambahkan Ijama', Qias, Ijtihad serta pendapat para ahli salaf as-shalih sebagai sumber pendidikan dalam Islam.

4. Tujuan pendidikan dalam Islam merupakan sebuah refleksi dari fungsi manusia untuk beribadah kepada Allah yaitu dengan menjadi keridhoanNya, berjihad untuk memberantas kebodohan, berjihad untuk mengabadikan Islam dengan sinaran ilmu.

5. Untuk pemikirannya tentang pendidik dan peserta didik, Nawawi mengungkapkan bahwa faktor kepribadian pendidik lebih penting daripada faktor yang lain, sedangkan dengan peserta didik sendiri hendaklah selalu berpegang teguh pada akhlak mulia dalam menghadapi guru, baik dalam proses belajar mengajar ataupun dalam berinteraksi dengan guru dalam kehidupan sehari-hari.

6. Untuk relevansi pemikirannya, penulis menyimpulkan bahwa pemikiran Nawawi terkait pendidik sangat relevan bila dikaitkan dengan kompetensi guru, yang mana semua unsur-unsur yang ada dalam kompetensi guru terdapat dalam pemikiran Nawawi terkait etika pendidik, walaupun dalam dunia modern banyak kompetensi-kompetensi baru yang harus dikuasai oleh para pendidik, dimana itu semua disesuaikan dengan perkembangan zaman seperti penguasaan guru terkait penggunaan teknologi informasi dan komunikasi dalam proses belajar mengajar. 
HIKMAH: Jurnal Pendidikan Islam Vol. 6, No. I Januari - Juni 2017

\section{DAFTAR PUSTAKA}

Abdurrahman An-Nahlawi. Pendidikan Islam di Rumah, Sekolah dan Masayarakat. Jakarta: Gema Insani, 2004.

Abuddin. Pemikiran Pendidikan Islam \& Barat, Jakarta: Rajagrafindo Persada, 2013.

Ahmad Syar'I. Filsafat Pendidikan Islam. Jakarta: Pustaka Firdaus, 2005

Azyumardi Azra. Pendidikan Islam, Tradisi dan Modernisasi Menuju Milenium Baru. Jakarta: Logos Wacana Ilmu, 1999.

Harun Asrohah. Sejarah Pendidikan Islam. Jakarta: Logos, 1999.

Hasan Langgulung. Asas asas Pendidikan Islam. Jakarta: Radar Jaya Offset, 1988.

Imam Machali. Pendidikan Islam \& Tantangan Globalisasi. Yogyakarta: Ar-Ruzz Media, 2004.

Janawi. Kompetensi Guru: Citra Guru Profesional. Bandung: Alfabeta, 2011.

Maragustam. Pemikiran Pendidikan Syekh Nawawi Al-Bantani. Yogyakarta: Datamedia, 2007.

Muhammad 'Atthiyyah Al-Abrasyi. Prinsip-prinsip dasar Pendidikan Islam. Bandung: Pustaka Setia, 2003.

Muhammad Arifin. Ilmu Pendidikan Islam, Tinjauan Teoritis dan Praktis Berdasarkan Pendekatan Interdisipliner. Jakarta: Bumi Aksara, 2003.

Muhammad Nawawi. Murah labayd Juz 2, Mesir: Darul Ihya'Al-Kutb Al'Arabiyah, Tanpa Tahun.

Muhammad Nawawi. Murah labayd, Mesir: Darul Ihya'Al-Kutb Al-'Arabiyah, Tanpa Tahun.

Muhammad Ulul Fahmi. Ulama Besar Indonesia Biografi dan karyanya. Kendal: Amanah Grafika, 2008.

Sudirman Tebba. Mengenalkan Wajah Islam Yang Ramah. Banten: Pustaka Irvan, 2007. 